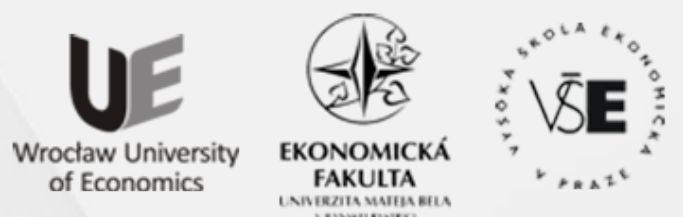

Conference Proceedings

Full TeXT PAPERS

edited by

Zofia Rusnak and Beata Zmyślona

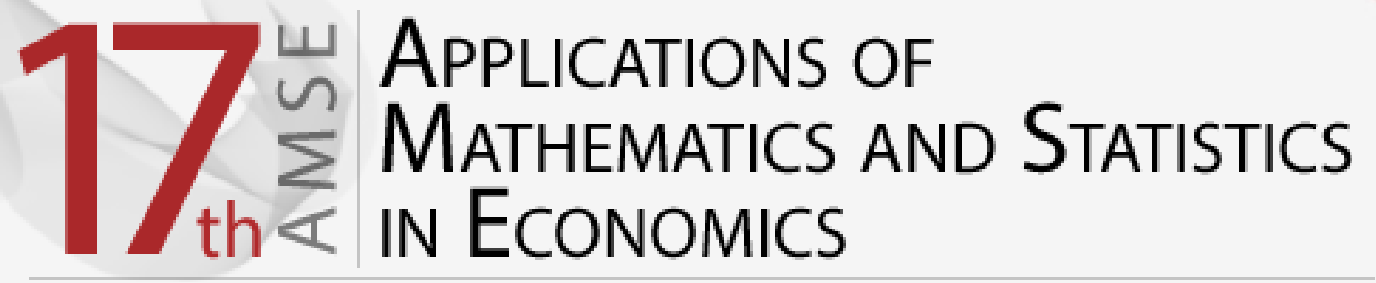

International Scientific Conference | Poland • 27-31 August 2014 
Scientific Committee

Richard Hindls, Stanislava Hronová, Rudolf Zimka, Walenty Ostasiewicz, Emília Zimková, Zofia Rusnak, Martin Bod'a

Organizing Committee

Beata Zmyślona, Cyprian Kozyra, Grzegorz Rogoziński, Kristýna Vltavská

\section{Reviewers}

Milan Bašta, Diana Bílková, Martin Bod'a, Joanna Dębicka, Tomáš Fiala, Jakub Fischer, Stanisław Heilpern, Karel Helman, Lenka Hudrlíková, Miroslav Hužvár, Nikola Kaspř́ková, Alena Kaščáková, Kamil Kladívko, Jindřich Klůfa, Pavol Král', Katarzyna Kuziak, Jana Langhamrová, Ivana Malá, Tomáš Marcinko, Luboš Marek, Miloš Maryška, Petr Mazouch, Zofia Mielecka-Kubień, Witold Miszczak, Petr Musil, Gabriela Nedelová, Walenty Ostasiewicz, Iva Pecáková, Viera Roháčová, Zofia Rusnak, Mária Stachová, Jana Špirková, Šárka Šustová, Jana Tepperová, Vladimír Úradníček, Kristýna Vltavská, Michal Vrabec, Dariusz Wawrzyniak, Henryk Zawadzki, Jaroslav Zbranek, Tomáš Zeithamer, Martin Zelený, Jan Zeman, Rudolf Zimka, Emília Zimková, Pavel Zimmermann, David Žižka

Layout

Martin Bod'a, Beata Zmyślona, Grzegorz Rogoziński

Front page design

Grzegorz Rogoziński

CD cover design

Beata Dębska

Articles published in the form submitted by the authors

All rights reserved. No part of this book may be reproduced in any form or in any means without the prior permission in writing of the Publisher

(C) Copyright by Wrocław University of Economics Wrocław 2014

ISBN 978-83-7695-421-9

Wydawnictwo Uniwersytetu Ekonomicznego we Wrocławiu

53-345 Wrocław, ul. Komandorska 118/120 www.ue.wroc.pl

Sprzedaż książek tel./fax 71 36-80-602

e-mail: econbook@ue.wroc.pl www.ksiegarnia.ue.wroc.pl 


\section{Contents}

Foreword

Diana Bílková: TL-Moments: Analogy of Classical L-Moments

Dagmar Blatná: Application of Robust Regression in the Analysis of Internet Access in European Countries

Martin Bod’a, Mária Kanderová: Rebalancing Issues in Tracking Error Variance Minimization

Martin Bod'a, Viera Roháčová: Application of Six Sigma Ideas to Timing Decisions at Financial Markets

Anton Dekrét, Rudolf Zimka: On the Price Hartwick's Task and Its Inverse in a Dynamic Model of an Economy with Exhaustible Resources

Joanna Dębicka, Agnieszka Marciniuk: Comparison of Reverse Annuity Contract and Reverse Mortgage on the Polish Market.

Petra Dotlačilová, Jitka Langhamrová: The Influence of Mortality Models for the Expected Future Life-time of Older People

Marek Ďurica, Lucia Švábová: Delta and Gamma for Chooser Options.

Vlastimil Farkašovský: New Concept of Pension Funds Performance Evaluation

Albert Gardon: The Normality of Weekly Relative Changes of the Freight Rate in Container Shipping.

Mária Grausová, Miroslav Hužvár, Jana Štrangfeldová: Healthcare Systems Efficiency in the Visegrád Group.

Stanisław Heilpern: Multiple Life Insurance - Pension Calculation

Alena Kaščáková, Gabriela Nedelová: Changes in Slovak Households' Economy

Igor Kollár, Pavol Král', Peter Laco: Methodology for Assessing Website Improvement in Corporate Environment.

Maciej Kostrzewski: Some Method of Detecting the Jump Clustering Phenomenon in Financial Time Series.

Cyprian Kozyra, Beata Zmyślona, Katarzyna Madziarska: Complementary Objective and Subjective Measures of Hospital Services Quality...

Pavol Král', Mária Stachová, Lukáš Sobíšek: Utilization of Repeatedly Measured Financial Ratios in Corporate Financial Distress Prediction in Slovakia

Ivana Malá: The Use of Finite Mixture Model for Describing Differences in Unemployment Duration

Lukáš Malec: Studying Economics and Tourism Industry Relations by Smooth Partial Least Squares Method Depending on Parameter. 
Tomáš Marcinko: Consequences of Assumption Violations Regarding Classical Location Tests.

Edyta Mazurek: The Income Tax Progression Depending on Social Insurance Contribution in Poland.

Petr Musil, Jana Kramulová, Jan Zeman: Regional Consumption Expenditures: An Important Starting Point for Regional Input-output Tables.

Katarzyna Ostasiewicz, Walenty Ostasiewicz: Good Life: From Political to Human Economy

Anna Sączewska-Piotrowska: Analysis of Poverty Transitions in Poland Using Multilevel Discrete-Time Event History Models

Martina Šimková, Petra Švarcová: Disadvantaged University Students in the Czech Republic.

Michal Široký: The Use of Short-term Business Statistics for Quarterly GDP Flash Estimates in the Czech Republic

Zdeněk Šulc, Hana Řezanková: Evaluation of Recent Similarity Measures for Categorical Data.

Lucia Švábová, Marek Ďurica: The Relationship Between the Finite Difference Method and Trinomial Trees

Kristýna Vltavská, Jaroslav Sixta: The Estimation of Final Consumption Expenditures

Lenka Vraná: Business Cycle Analysis: Tracking Turning Points

Janusz Wywiał: On Bayesian Testing in Auditing

Emília Zimková: Window Analysis of Supper-efficiency Change: Case of the Slovak Banking System ....

Beata Zmyślona: Statistical Modelling of the Impact of Diabetes on the Risk of Hospitalization 


\title{
REGIONAL CONSUMPTION EXPENDITURES: AN IMPORTANT STARTING POINT FOR REGIONAL INPUT-OUTPUT TABLES
}

\author{
PETR MUSIL \\ University of Economics in Prague, Faculty of Informatics and Statistics, Department of Economic \\ Statistics, \\ Nám. W. Churchilla 4, 13067 Praha 3, Czech Republic \\ email: petr.musil@vse.cz
}

\section{JANA KRAMULOVÁ}

University of Economics in Prague, Faculty of Economics, Department of Regional Studies,

Nám. W. Churchilla 4, 13067 Praha 3, Czech Republic

email: jana.kramulova@vse.cz

\section{JAN ZEMAN}

University of Economics in Prague, Faculty of Informatics and Statistics, Department of Economic

Statistics,

Nám. W. Churchilla 4, 13067 Praha 3, Czech Republic

email: jan.zeman@vse.cz

\begin{abstract}
Construction of regional input-output tables represents a difficult research task. It is much more complicated than creation of national input output tables, because it includes not only international relations, but also interregional relations and the necessity of detailed data is very high. One of the most important starting points is the matrix of regional consumption expenditures. These data are not officially published, but were estimated in the preceding research.

It is essential to estimate not only regional final consumption expenditures of households, but also of general government and non-profit institutions serving households (NPISHs). These data are estimated for 14 Czech NUTS 3 regions taking into account all possible data sources accessible. The results are computed for the year 2011 using the most up-to-date national accounts information available. Moreover, regional price levels are taken into consideration. Regional households' consumption expenditures are subsequently compared with net disposable income of households and selected social statistics indicators and a brief regional analysis of well-being of households is carried out.

Data on regional consumption expenditures need to be transformed to become suitable for regional input-output modeling. Therefore, commodity structure of consumption expenditures is estimated and all figures are transferred from purchasers' prices to basic prices. Further, the applicability of regional consumption expenditures for multi-regional input-output (MRIO) model is discussed in the paper.
\end{abstract}

Key words: regional input-output tables, regional consumption expenditures, expenditure approach to GDP estimate.

DOI: $10.15611 / a m s e .2014 .17 .22$ 


\section{Introduction}

Construction of regional input-output tables (RIOTs) is a very complicated issue; however, it constantly attracts attention of researchers. Having RIOTs at a disposal means that you can easily analyze relations among different regions or estimate the response of one or more regions to e.g. price shocks or demand shocks in other regions. The aim of this paper is to present the procedure of construction of regional consumption expenditures matrix, which is a necessary input for the compilation of regional input-output model.

Construction of RIOTs is a long-term task including several phases. The first consists in preparation of input data matrices. One of the necessary input matrices is the matrix of regional consumption expenditures that comprise final household consumption expenditures (FHCE), final general government consumption expenditures (FGGCE) and final NPISHs consumption expenditures (FNPISHCE). These data are not published for NUTS 3 regions in the Czech Republic. Therefore, we had to regionalize data available for the national economy or NUTS 2 regions (see section 2). The data obtained are further analyzed and regional price levels are taken into consideration. Moreover, regional FHCE are compared with net disposable income of households and selected social statistics indicators and a brief regional analysis of well-being of households is carried out in sections 3 and 4. Section 5 presents the transformation of regional consumption expenditures data into commodity structure and subsequently from purchasers' prices to basic prices. In section 6 the applicability of regional consumption expenditures for multi-regional input-output (MRIO) model is discussed.

\section{Regionalization of consumption expenditures}

It was already stated, that consumption expenditures are published in national accounts for the whole Czech Republic only. For the case of FHCE it is also possible to take partly into account data from Household Budget Survey (HBS) which are available since 2011 for NUTS 2 regions as well. However, these data have some limitations. Firstly, they are focused just on monetary expenditures. It means, that some expenditures, e.g. imputed rentals for housing or FISIM, are not covered at all. Secondly, as surveyed data they are strongly influenced by the willingness of respondents to report all expenditures. This leads again to underestimation of some expenditures, mainly alcoholic beverages, tobacco products and narcotics.

For each of $48 \mathrm{CZ}$-COICOP categories the most appropriate regionalization key was found and top-down method was applied. If no suitable indicator was available, HBS data would be used for estimate. Such a regionalization was done in the previous research for the year 2009 (Kramulová \& Musil, 2013, 818-822) and updated for the year 2011. The regionalization is now performed in a more precise way, as new data sources were applied. Table 1 summarizes the regionalization keys for CZ-COICOP categories. Using these keys weight schemes of FHCE were determined for each category. Sometimes, the weights had to be slightly adjusted, especially in the case of HBS data, because some regions were constantly overestimated (compared to other regional indicators such as net disposable income).

Concerning FGGCE and FNPISHCE the main data source applied were supply and use tables (SUT) in CZ-CPA classification. The whole non-market output (all categories) was regionalized by compensations of employees. In case of social benefits in kind different weights were applied for different CZ-CPA categories. Table 2 shows the regionalization keys for social benefits in kind for FGGCE. Since FNPISHCE are much smaller in value, just for 


\section{Amencrous of \\ Mathematics and Statistics \\ IN ECONOMICS \\ International Scientific Conference | Poland • 27-31 August 2014}

CZ-CPA 30 the regionalization key Medical technology was used, otherwise Mid-year population was employed.

Table 1. Summary of regionalization keys applied for different CZ-COICOP categories.

\begin{tabular}{cc}
\hline Data source for the key & CZ-COICOP category \\
\hline HBS 2011 & Other categories not mentioned below \\
Mid-year population 18+ & Alcoholic beverages (02100) \\
Mid-year population & Tobacco (02200) \\
Drug users (Prague Hygiene Station & Narcotics (02300) \\
Annual report 2011) & Actual rentals for housing (04100), Imputed rentals for \\
National accounts (CZSO) & housing (04200) \\
& Maintenance and repair of the dwelling (04300), Water \\
Dwellings in regions & supply and miscellaneous services relating to the \\
& dwelling (04400) \\
Energy Regulatory Office Statistics & Electricity, gas and other fuels (04500) \\
Households in regions & Furnishings, household equipment and routine \\
& household maintenance (05000), Communication \\
Institute of Health Information and & (08000), Insurance (12500) \\
Statistics of the Czech Republic & Health (06000), Social protection (12400) \\
Car Importers Association & Purchase of vehicles (07100) \\
Ministry of Transport & Operation of personal transport equipment (07200) \\
Ministry of Education, Youth and & Post-secondary non-tertiary education (10300), \\
Sports Statistics & Tertiary education (10400), Education not definable by \\
Rozkoš bez rizika Association & level (10500) \\
Ministry of Regional Development & Prostitution (12200) \\
\hline Source: Authors. & FISIM (12610)
\end{tabular}

Table 2. Summary of regionalization keys applied for different CZ-CPA categories.

\begin{tabular}{cc}
\hline Data source for the key & CZ-CPA category \\
\hline Mid-year population & $\begin{array}{c}\text { Other categories not mentioned below } \\
\text { Medicine costs of hospitals }\end{array}$ \\
Medical technology & $\begin{array}{c}\text { Computer, electronic and optical products (26), Other } \\
\text { preparations (21) }\end{array}$ \\
$\begin{array}{c}\text { transport equipment (30), Other manufactured goods } \\
\text { Revenues of hospitals from health } \\
\text { insurance }\end{array}$ & Human health services (86) \\
\hline
\end{tabular}

Source: Authors. 


\section{Analysis of results}

For more reliable results we also incorporated in the computations regional price levels whose estimation is another important issue being solved all around the world (e.g. Alberola \& Marques, 2001, Hayes, 2005, Aten et al., 2012, Brandt \& Holz, 2006, Blien et al., 2009 or Roos, 2006). Our approach is based on OECD and Eurostat methodology (European Commission, 2006) and is described in Musil et al. (2012). Regional price levels were estimated for the year 2007, because no newer data are available. However, it can be expected that changes in regional price levels are over a 7-year period insignificant, because they are caused mainly by different level of economic development, rate of unemployment etc. Therefore, application of 2007 regional price levels on 2011 FHCE will not cause a big distortion of results.

Table 3 shows estimated FHCE in regional breakdown. The highest expenditures per capita are observed in the capital city Praha (almost $30 \%$ above average) followed by Středočeský kraj (surrounding region of the capital city). Expenditures per capita in all other regions are below the average of the whole Czech Republic. This comparison is influenced by different regional price levels; therefore FHCE are expressed in regional purchase power standard (RPPS) that enables to compare real values. Praha remains after this adjustment still the region with the highest level of well-being measured by amount of goods and services purchased by households, but the difference declined from almost $30 \%$ to just $7 \%$.

Table 3. FHCE estimate, 2011

\begin{tabular}{|c|c|c|c|c|}
\hline Region & $\begin{array}{c}\text { FHCE per } \\
\text { capita in } \\
\text { CZK }\end{array}$ & $\begin{array}{l}\text { FHCE per capita, \% } \\
\text { structure }(C Z=100)\end{array}$ & RPPP & $\begin{array}{l}\text { FHCE per capita in RPPS, } \\
\% \text { structure }(C Z=100)\end{array}$ \\
\hline Praha & 235081 & 129.4 & 120.8 & 107.0 \\
\hline Stř̌edočeský kraj & 185138 & 101.9 & 102.6 & 99.3 \\
\hline Jihočeský kraj & 170668 & 93.9 & 97.5 & 96.4 \\
\hline Plzeňský kraj & 171572 & 94.4 & 97.1 & 97.3 \\
\hline Karlovarský kraj & 171782 & 94.5 & 101.3 & 93.3 \\
\hline Ústecký kraj & 170765 & 94.0 & 94.1 & 99.8 \\
\hline Liberecký kraj & 173450 & 95.4 & 100.2 & 95.2 \\
\hline Královéhradecký kraj & 171481 & 94.4 & 96.2 & 98.1 \\
\hline Pardubický kraj & 172175 & 94.7 & 98.9 & 95.8 \\
\hline Kraj Vysočina & 171683 & 94.5 & 95.1 & 99.3 \\
\hline Jihomoravský kraj & 181345 & 99.8 & 104.6 & 95.4 \\
\hline Olomoucký kraj & 169759 & 93.4 & 96.6 & 96.7 \\
\hline Zlínský kraj & 171935 & 94.6 & 100.8 & 93.9 \\
\hline Moravskoslezský kraj & 171920 & 94.6 & 96.9 & 97.6 \\
\hline Czech Republic & 181739 & 100.0 & 100.0 & 100.0 \\
\hline
\end{tabular}

Source: Czech Statistical Office, Authors. 
Expenditures in other regions are below the national average, with the lowest value in Karlovarský kraj being the least developed region with relatively high price level caused by tourism and high proportion of foreigners living in Karlovy Vary (regional city).

Table 4 describes the estimate of "Use of disposable income" account of households in the year 2011. Net disposable income of households is published by the Czech Statistical Office, other items were estimated by the authors. Households in all regions are able to create savings, though savings in Karlovarský kraj are quite tight.

\section{Regional analysis of well-being of households}

It is useful to compare FHCE with net disposable income, because this indicator shows the volume of resources that household sector has at a disposal for final consumption expenditures and savings (Hronová et al., 2009, 155). Region with the lowest standard of living is Karlovarský kraj. Households in this region can buy the least amount of goods and services (- $6.7 \%$ in comparison to national average); moreover, they spend almost the whole net disposable income on FHCE. On the contrary, at the top of the ranking is capital city Praha, where the households may purchase the highest amount of goods and services. Nevertheless, the at-risk-of-poverty rate $^{1}$ is the highest in Praha region, because of unequal distribution of income (Dvornáková, 2012).

Table 4. Households: Use of disposable income account, 2011

\begin{tabular}{ccccc}
\hline Region & $\begin{array}{c}\text { Net disposable } \\
\text { income of } \\
\text { households }\end{array}$ & $\begin{array}{c}\text { Adjustment for the change } \\
\text { in net equity of households } \\
\text { in pension funds reserves }\end{array}$ & FHCE & $\begin{array}{c}\text { Net } \\
\text { savings }\end{array}$ \\
\hline Praha & 309636 & 2143 & 291017 & 20762 \\
Středočeský kraj & 263109 & 1823 & 235698 & 29234 \\
Jihočeský kraj & 115236 & 968 & 108529 & 7675 \\
Plzeňský kraj & 107398 & 887 & 98053 & 10232 \\
Karlovarský kraj & 52140 & 469 & 52139 & 470 \\
Ústecký kraj & 141628 & 1263 & 141495 & 1396 \\
Liberecký kraj & 78316 & 660 & 75994 & 2982 \\
Královéhradecký kraj & 99571 & 841 & 95009 & 5403 \\
Pardubický kraj & 91411 & 759 & 88887 & 3283 \\
Kraj Vysočina & 92207 & 746 & 87897 & 5056 \\
Jihomoravský kraj & 215251 & 1706 & 211200 & 5757 \\
Olomoucký kraj & 110147 & 942 & 108450 & 2639 \\
Zlínský kraj & 105290 & 856 & 101372 & 4774 \\
Moravskoslezský kraj & 217109 & 1881 & 211913 & 7077 \\
Czech Republic & 1998449 & 15944 & 1907653 & 106740 \\
\hline
\end{tabular}

Source: Czech Statistical Office, Authors.

\footnotetext{
${ }^{1}$ Dvornáková (2012) presents the calculation at the regional level. Eurostat publishes regional indicators that are based on national threshold. According to Eurostat data Praha is the region with the lowest at-risk-of-poverty rate, but the results are affected by regionally different price levels and distribution of income (that are not taken into account).
} 


\section{Data transformation}

All calculations related to FHCE were done in "purpose classification" CZ-COICOP that is the most important one for such an analysis and at the same time the most widespread in the data sources. However, the data have to be transformed to "product classification" CZ-CPA as input-output tables are compiled in this classification. National transformation key was used for the transformation and 14 matrices (CZ-CPA x CZ-COICOP) of FHCE were computed. Non-market output is generally recorded in classification CZ-NACE and according to ESA 1995 standard matrix of non-market output is always diagonal, i.e. NACE $=$ CPA. Vector of social benefits in kind is recorded again in product classification.

The basis for estimate of regional symmetric input-output tables forms the use table at basic prices. The difference between purchasers' prices and basic prices consists in so-called valuation sets: value added tax (VAT), transport margins, trade margins, taxes on products without VAT and subsidies on products. All valuation sets data are available as the Czech Statistical office compiles SUT for each version of annual national accounts (preliminary, semi-definitive and definitive) data at the national level. This practice is not obvious in all EU countries, as some states provide these data very late or do not provide them at all. All valuation sets were allocated to regions proportionally to FHCE at purchasers' prices for each product. This assumption is suitable for taxes and subsidies because no special regional taxes are applied in the Czech Republic and the rate of taxation for a product is the same in all regions. The question is, whether the rate of margins differs from region to region. We are convinced that this assumption is acceptable because regional markets in the Czech Republic are very similar. No valuation sets are applied on part of FGGCE and FNPISHCE that have its origin in non-market output.

\section{Applicability of regional consumption expenditures for multi-regional input-output (MRIO) model}

We have emphasized in the introduction that the construction of RIOTs is a very complicated task. One of the main obstacles is the non-availability of the data, as the lower the regional level is, the more complicated data availability occurs. Previous sections showed that even estimating regional expenditures is a long-term research question. Another reason is a very problematic measuring of foreign trade at the regional level (see e.g. Bracalente \& Perugini, 2010, Matlovič et al., 2008 or Harris \& Liu, 1998). The theory distinguishes two basic input-output models - inter-regional (IRIO) and multi-regional (MRIO). The latter requires significantly less data; therefore, the aim of further research is to build a MRIO model for Czech economy (14 NUTS 3 regions). For deeper theory on regional input-output models see e.g. Miller \& Blair (2009). The main difference among inter-regional and multiregional models lies in the computation of technical coefficients matrix $\mathbf{A}$ (in case or RIOTs defined as $\mathbf{A}^{\mathbf{r}}$ or $\mathbf{A}^{\mathbf{r r}}$ ). Whereas in case of the IRIO model, we take into account the region of origin as well as region of destination, in case of the MRIO model the region of origin is neglected.

The starting point of our model is the matrix of regional consumption expenditures presented in this paper. The next sequential step will be the estimation of inter- and intraregional foreign trade, in a commodity breakdown as well and find a balance for each product in each region. And last but not least the matrices of output and intermediate consumption are necessary to be computed for the model to be complete. 


\section{Conclusion}

This paper presented the procedure of construction of regional consumption expenditure matrix useful for further application in regional input-output model. The first step was to regionalize national values of FHCE, FGGCE and FNPISHCE. The most suitable regionalization keys were found and using top-down method, weights schemes were produced. The results were analyzed and compared with net disposable income as an indicator of well-being of households. The highest level of standard of living is observed in Praha. On the bottom of ranking list is Karlovarský kraj where well-being of households is influenced by a relatively high price level and a low level of economic performance. Further, the matrix was transformed firstly to CZ-CPA classification and after that from purchasers' prices to basic prices. In this form it can already be applied in regional input-output models. Building of MRIO model is the final aim of our research. This paper is the first step in our research.

\section{Acknowledgements}

This paper was supported by Grant Agency of the Czech Republic GACR No. 13-15771S "Regionalization of GDP estimate using expenditure approach".

\section{References}

1. ALBEROLA, E., MARQUES, J. M. 2001. On the Evolution of Relative Prices and Its Nature at the Regional Level: The Case of Spain. In Journal of Regional Science, 2001, vol. 41, no. 3, pp. 451-74.

2. ATEN, B H., FIGUEROA, E. B., MARTIN, T. M. 2012. Regional Price Parities for States and Metropolitan Areas, 2006-2010. In Survey of Current Business, 2012, vol. 92, no. 8 , pp. 229-242.

3. BLIEN, U. ET AL. 2009. Regional Price Levels and the Agglomeration Wage Differential in Western Germany. In Annals of Regional Science, 2009, vol. 43, no. 1, pp. 71-88.

4. BRACALENTE, B., PERUGINI, C. 2010. The components of regional disparities in Europe. In Annals of Regional Science, 2010, vol. 44, no. 3, pp. 621-645.

5. BRANDT, L., HOLZ, C. A. 2006. Spatial Price Differences in China: Estimates and Implications. In Economic Development and Cultural Change, 2006, vol. 55, no. 1, pp. 43-86.

6. DVORNÁKOVÁ, T. 2012. At-Risk-of-Poverty-Threshold. In Statistika, Economy and Statistics Journal, 2012, vol. 49, no. 2, pp. 44-61.

7. EUROPEAN COMMISSION. 2006. Eurostat-OECD Methodological Manual on Purchasing Power Parities. Paris: European Communities/OECD. 2006. ISBN 92-7901868-X. ISSN 1725-0048.

8. HARRIS, R. I. D., LIU, A. 1998. Input-output modelling of the urban and regional economy: The importance of external trade. In Regional Studies, 1998, vol. 32, no. 9, pp. 851-862.

9. HAYES, P. 2005. Estimating UK Regional Price Indices, 1974-96. In Regional Studies, 2005, vol. 39, no. 3, pp. 333-344.

10. HRONOVÁ ET AL. 2009. Národní účetnictví: nástroj popisu globální ekonomiky [National Accounting: a Tool for Description of the Global Economy] Praha: Nakladatelství C. H. Beck. 2009. 326 pp. ISBN 978-80-7400-153-6.

11. KRAMULOVÁ, J., MUSIL, P. 2013. Experimentální odhad složek výdajové metody regionálního HDP v ČR [Experimental Estimate of Components of Expenditure Approach 
to Regional GDP in the Czech Republic]. In Politická ekonomie, 2013, vol. 61, iss. 6, pp. 814-833.

12. MATLOVIČ, R., KLAMÁR, R., MATLOVIČOVÁ, K. 2008. Vývoj regionálnych disparít začiatkom 21. storočia na Slovensku vo svetle vybraných indikátorov [Development of regional disparities in Slovakia at the beginning of 21 st century based on the selected indicators]. In Regionální studia, 2008, vol. 2, no. 2, pp. 2-12.

13. MILLER, R. E., BLAIR, P. D. 2009. Input-output analysis: foundations and extensions. Cambridge: Cambridge University Press, 2009, 750 pp. ISBN 978-0-521-73902-3.

14. MUSIL, P. ET AL. 2012. Application of Regional Price Levels on Estimation of Regional Macro-Aggregates Per Capita in PPS. In Statistika, Economy and Statistics Journal, 2012, vol. 49, no. 4, pp. 4-13.

15. ROOS, M. W. M. 2006. Regional Price Levels in Germany. In Applied Economics, 2006, vol. 38 , no. 13, pp. 1553-1566. 